\title{
THE INFLUENCE OF PROCESS PARAMETERS ON THE MECHANICAL PROPERTIES OF FRICTION-STIR-WELDED JOINTS OF 2024 T351 ALUMINUM ALLOYS
}

\author{
VPLIV PROCESNIH PARAMETROV, IZDELANIH S TORNO \\ VRTILNIM VARJENJEM, NA MEHANSKE LASTNOSTI SPOJEV \\ ALUMINIJEVE ZLITINE 2024/T351
}

\author{
Miodrag Milčić1*, Tomaž Vuherer², Igor Radisavljevićc ${ }^{3}$, Dragan Milčić1, \\ Janez Kramberger ${ }^{2}$ \\ ${ }^{1}$ University of Niš, Faculty of Mechanical Engineering, Aleksandra Medvedeva 14, 18000 Niš, Republic of Serbia \\ ${ }^{2}$ University of Maribor, Faculty of Mechanical Engineering, Smetanova ulica 17, 2000 Maribor, Slovenia \\ ${ }^{3}$ Military Technical Institute, Ratka Resanovića 1, 11000 Beograd, Republic of Serbia
}

Prejem rokopisa - received: 2019-03-18; sprejem za objavo - accepted for publication: 2019-05-17

doi: $10.17222 /$ mit.2019.062

\begin{abstract}
The aim of this paper is to analyze the influence of the dominant parameters of Friction Stir Welding (FSW) on the mechanical properties of welded joints. Experimental investigations were carried out on 6-mm-thick plates made of the aluminum alloy AA 2024 T351. The rotation speed of the FSW tool was a constant $750 \mathrm{~min}^{-1}$, and the welding speed was (73, 116 and 150$)$ $\mathrm{mm} / \mathrm{min}$. The obtained welds were free of imperfections and with an acceptable flat front surface. The testing of the mechanical properties of the FSW welded joint concerned the Vickers hardness test, tensile testing, bending tests, and Sharpy pendulum impact tests. The profile of the hardness distribution across the welded joint is made along three horizontal directions: near the face, in the middle and near the root of the weld. For the Sharpy impact testing, an instrumented pendulum Amsler RPK 300 was used. The FSW process generates three different microstructural zones: the nugget zone (NZ), the thermomechanically affected zone (TMAZ), and the heat-affected zone (HAZ), which were examined by optical microscopy and scanning electron microscopy (SEM). All the results of the experimental research indicated that the welding parameters $n=750 \mathrm{~min}^{-1}$ and $v=116$ $\mathrm{mm} / \mathrm{min}$ give welded joints with the best mechanical properties.

Keywords: friction stir welding, aluminum alloy 2024 T351, mechanical properties, welded joints
\end{abstract}

$\mathrm{V}$ članku avtorji opisujejo in analizirajo vpliv prevladujočih procesnih parametrov na mehanske lastnosti spojev, ki so izdelani s torno vrtilnim varjenjem (FSW). Eksperimentalne raziskave so izvajali na $6 \mathrm{~mm}$ debelih ploščah iz Al zlitine tipa AA 2024, ki so bile toplotno obdelane s postopkom T351. Varjenje so izvajali pri konstantni hitrosti vrtenja FSW orodja, 750 obratov na minuto in hitrostih varjenja (73, 116 in 150) $\mathrm{mm} / \mathrm{min}$. Izdelani zvari so bili brez napak in s sprejemljivo kakovostjo površine. Mehanske lastnosti zvarov (FSW spojev) so ovrednotili z nateznim in upogibnim preizkusom, preizkusom udarne žilavosti po Charpyju in določitvijo trdote po Vickersu. Profil porazdelitve trdote v zvaru so določili v treh vodoravnih smereh: blizu čela zvara, v sredini in v korenu zvara. Za določitev udarne žilavosti so uporabili inštrumentirano kladivo Amsler RPK 300. FSW proces je ustvaril tri različne mikrostrukturne cone, ki so jih avtorji preiskovali z optično in vrstično elektronsko mikroskopijo; z grobo zrnato cono (NZ), termomehansko vplivano cono (TMAZ) in toplotno vplivano cono (HAZ). Na osnovi eksperimentalnih rezultatov avtorji prispevka ugotavljajo, da so najboljše mehanske lastnosti dosegljive pri naslednjih parametrih varjenja: $n=$ $750 \mathrm{~min}^{-1}$ in $v=116 \mathrm{~mm} / \mathrm{min}$.

Ključne besede: torno vrtilno varjenje, Al zlitina 2024/T351, mehanske lastnosti, varjeni spoji

\section{INTRODUCTION}

Wayne Thomas, and his team of researchers, at The Welding Institute (TWI) in the UK patented the Friction Stir Welding (FSW) process in 1991. As a solid-state joining technique it was initially applied to aluminum alloys. ${ }^{1}$ This process has a particularly common application in welding aluminum alloys used in the automotive and aerospace industries. This welding process allows joining of the materials that are hardly weldable with a conventional welding processes. The FSW process can provide better mechanical properties of the compound than conventional methods. In order to

*Corresponding author's e-mail:

miodrag.milcic@masfak.ni.ac.rs (Miodrag Milčić) achieve a quality joint, a lower amount of energy is required than the melting process of the material. It is a relatively clean welding technology that does not pollute the environment. The great importance of applying this welding process is the appearance of very small deformations when welding thin sheets of high length, which is not obtained by any other method.

FSW is most commonly used for welding aluminum alloys, which are difficult to weld with conventional welding processes. The principle of obtaining inseparable compounds by FSW is shown in Figure 1. FSW is performed by a special tool on the parts to be joined. The FSW process consists of four phases: 1) plunging phase, 2) dwelling phase, 3) welding phase, and 4) exit or retract phase. ${ }^{2}$ 


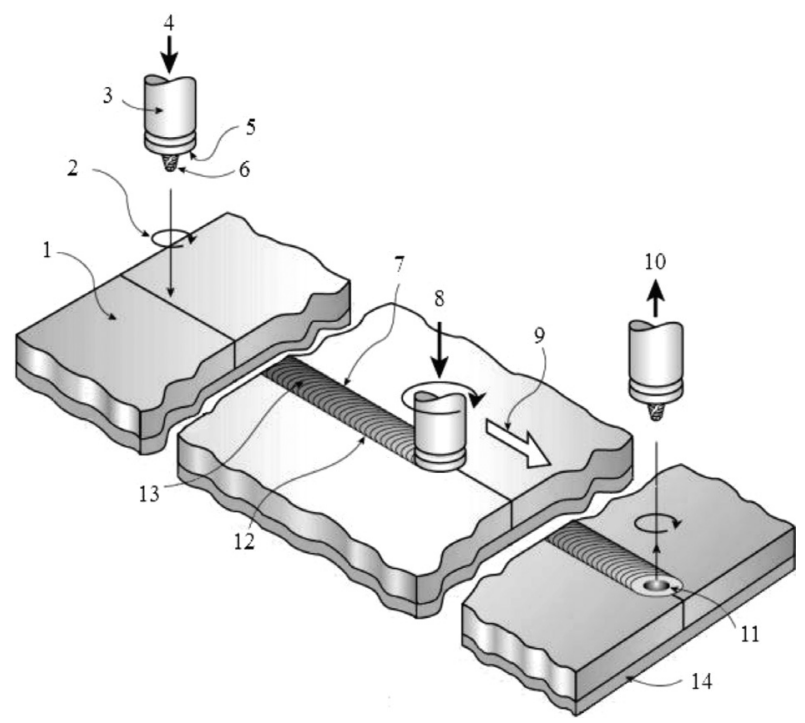

Figure 1: Illustrated scheme of friction stir welding: 1 - base metal, 2 - direction of tool rotation, 3 - weld tool, 4 - downward movement of tool, 5 - tool shoulder, 6 - pin, 7 - advancing side of weld, 8 - axial force, 9 - direction of welding, 10 - upward movement of tool, 11 exit hole, 12 - retreating side of weld, 13 - weld face and 14 - base plate

The tool rotates around its axis and is further axially moving relative to the base metal parts to be joined. The function of the tool is:

- pre-heating of the base metal in the welding zone,

- deforming and mixing of materials,

- making friction stir weld.

Pre-heating of the base metal in the welding zone involves friction on the contact of the tool and the base metal, which is why the heat is generated in the contact, which facilitates the deformation of the base material and its mixing into the monolithic joint. In the initial phase (plunging phase) of the penetration of the tool, heating is primarily a result of the friction between the tool pin and the workpiece. The tool penetrates the contact of the shoulder of the tool and workpiece. After the completion of the plunging phase, the tool continues to rotate in order to stabilize the material and prepare for the phase of welding (dwelling phase). By rotation of the tool pin, the material of the workpieces is cut, deformed and mixed with the previously deformed material. The tool pin causes the movement of parts of the base metal around the tool and towards the axis of the tool. By translating the tool, a portion of the deformed material moves and deposits it in the zone behind it, thus forming a weld joint (welding phase).

The welding cycle ends with the fourth phase, with the tool exiting the material (by vertical movement) (Figure 1).

Welding parameters, tool geometry, and joint construction have a significant impact on the structure of materials flow and temperature distribution, influencing the development of the microstructure of the material. For the FSW process, two parameters are very important: ${ }^{4-8}$
- the tool's rotational speed $\left(\mathrm{min}^{-1}\right)$ in the clockwise direction or in the opposite direction,

- the speed of the tool along the line of the joint.

A peculiar feature of friction stir welds is the complex microstructure of the welded joint in which they form different welding zones that are drastically different from the basic metals that are welded. The microstructure of the welded joint obtained by the FSW method significantly depends on the structural tool design, the rotating speed, the welding speed, the pressure of the tool on the plates along the vertical axis, the angle under which the tool acts on the material and the characteristics of the material being welded. In the microstructure of the welded joint, several zones can be identified: the heataffected zone (HAZ), the thermo-mechanical affected zone (TMAZ), the nugget zone (NZ) and the base material. $^{9-11}$

It is very important to choose the right combination of welding parameters in order to obtain a welded joint of the corresponding quality without defects. ${ }^{12}$

The main objective of the research is the analysis of the influence of the most important parameters of FSW welding, tool rotating speed and welding speed, on the structural and mechanical properties of FSW joints from aluminum alloy AA 2024 T351. ${ }^{13}$

\section{EXPERIMENTAL PART}

Experimental investigations were focused on determining the impact of the FSW on the metallurgical and mechanical properties of the welded joints. The basic material is an AlCu4Mg1 AA 2024-T351 alloy, which is
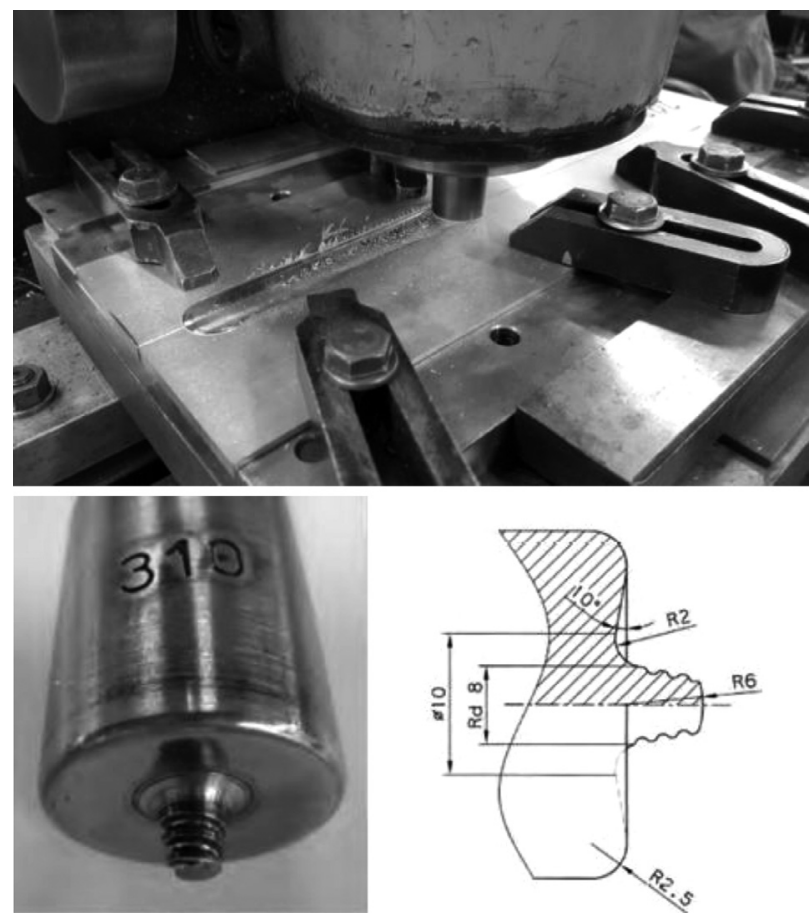

Figure 2: a) Conventional milling machine for FSW and b) FSW tool 
difficult to weld with conventional welding processes. The chemical and mechanical properties of the basic material are given in Table $\mathbf{1}$.

Table 1: Chemical composition of AA 2024-T351

\begin{tabular}{|c|c|c|c|c|c|c|c|}
\hline $\begin{array}{c}\text { Chemical } \\
\text { composition }\end{array}$ & $\mathrm{Cu}$ & $\mathrm{Mg}$ & $\mathrm{Mn}$ & $\mathrm{Fe}$ & $\mathrm{Si}$ & $\mathrm{Zn}$ & $\mathrm{Ti}$ \\
\hline$w / \%$ & 4.70 & 1.56 & 0.65 & 0.17 & 0.046 & 0.11 & 0.032 \\
\hline
\end{tabular}

The dimensions of the welding samples were $500 \mathrm{~mm}$ length, $65 \mathrm{~mm}$ width and $6 \mathrm{~mm}$ depth. Below the welding samples was placed an austenitic plate in order to maintain the heat in the welded joint area. A milling machine was used for welding. The length of the weld is about $400 \mathrm{~mm}$.

Figure 2 shows the conventional milling machine that was used for welding, and a tool for welding a butt FSW joint. The most important parameters of the FSW welding are the welding speed and the tool's rotational speed.

Experimental research was performed with a constant number of tool rotations, and a variation of the welding speed (Table 2).

Table 2: Friction-stir-welding parameters

\begin{tabular}{|c|c|c|c|c|c|}
\hline Sample & $\begin{array}{c}\text { Rotation } \\
\text { rate } \\
n \\
\min ^{-1}\end{array}$ & $\begin{array}{c}\text { Welding } \\
\text { speed } \\
v \\
\mathrm{~mm} / \mathrm{min}\end{array}$ & $\begin{array}{c}\text { Ratio } \\
n / v \\
\mathrm{rev} / \mathrm{mm}\end{array}$ & $\begin{array}{c}\text { Ratio } \\
v / n \\
\mathrm{~mm} / \mathrm{rev}\end{array}$ & $\begin{array}{c}\text { Ratio } \\
n^{2} / v \\
\mathrm{rev}^{2} / \mathrm{m} \cdot \mathrm{min}\end{array}$ \\
\hline$A-I$ & \multirow{3}{*}{750} & 73 & 10.27 & 0.0974 & 7705.5 \\
\hline B - II & & 116 & 6.47 & 0.155 & 4849.14 \\
\hline $\mathrm{C}-\mathrm{III}$ & & 150 & 5 & 0.2 & 3750 \\
\hline
\end{tabular}

After completion of the welding process, welded joints were tested with non-destructive methods. For this purpose, visual and radiographic control of samples was performed. On the welded samples there were no detected welding imperfections.

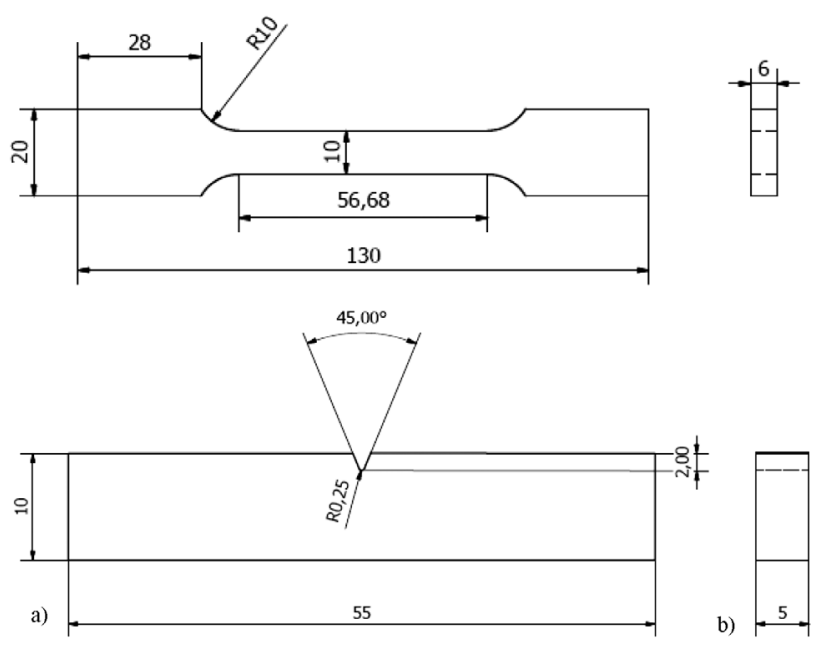

Figure 3: Dimensions of the tensile specimens: a) and b) the Sharpy impact-test specimens
From the FSW samples we made specimens for the tensile testing, specimens with a V-notch at the different position of the FSW joint for the Charpy pendulum impact testing and specimens for the fracture mechanics parameter testing. The dimensions of the specimens for the tensile testing and for the Charpy pendulum impact testing are shown in Figure 3.

For the metallographic examination of the FSW welded joint, preparation of the specimens by grinding, polishing and chemical treatment using Tucker's reagent (45 mL HCl, $15 \mathrm{~mL} \mathrm{HNO}_{3}, 5 \mathrm{~mL} \mathrm{HF}$ and $25 \mathrm{~mL} \mathrm{H}_{2} \mathrm{O}$ ) was carried out. The metallographic observation was performed by optical microscopy using the optical microscope Leica M205A. Tensile testing was performed at room temperature on standard ASTM E8M specimens made perpendicular to the welded joint. Bending specimens and the bending test procedure on the welded joints are defined by the EN 910 standards. Bending specimens were loaded on the faces and roots of the welded joint.

The Vickers hardness measurement was carried out in a cross-section of the welded joint, perpendicular to the direction of welding, using a digitally controlled hardness tester (Model HVS-1000 digital display microhardness tester). The aim of this testing of the welded joints is to determine the hardness of the welded seams, the HAZ, the TMAZ, the nugget zone and the basic materials for their mutual comparison. The hardness diagrams were obtained by measuring the hardness along three horizontals (close to the face of the weld, in the middle of the weld and near the welding root). The hardness was measured at every $0.5 \mathrm{~mm}$.

Impact toughness testing using Sharpy's pendulum was performed at room temperature using an instrumented pendulum Amsler RPK 300. The impact tough-

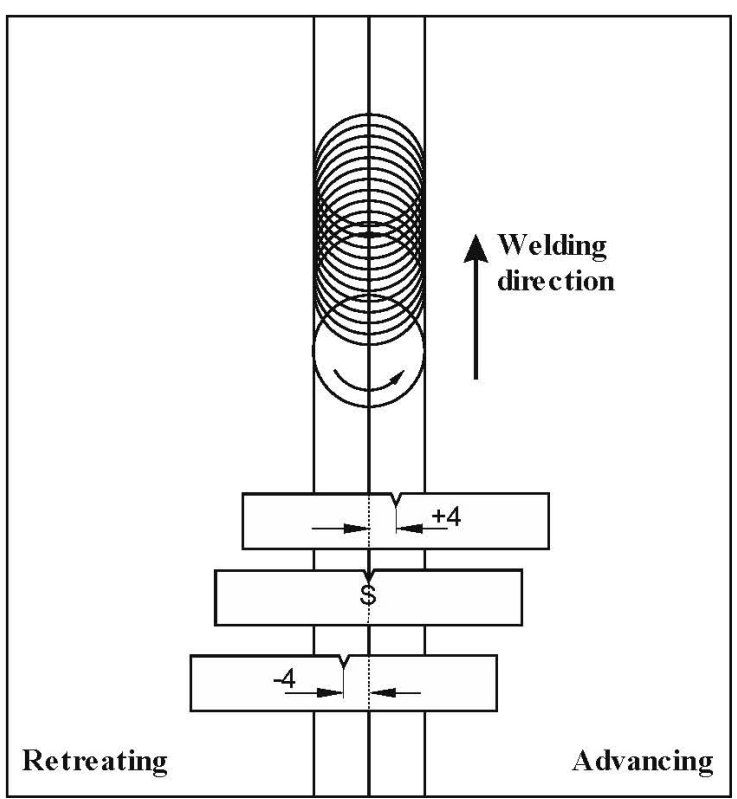

Figure 4: Positions on FSW joint in which V-notch was made on the impact test specimens 
M. MILČIĆ et al.: THE INFLUENCE OF PROCESS PARAMETERS ON THE MECHANICAL PROPERTIES...

ness according to the Sharpy's method is determined by testing a $(6 \times 10 \times 55) \mathrm{mm}$ specimens with a V-notch having a depth of $2 \mathrm{~mm}$ and a radius of $0.25 \mathrm{~mm}$.

The Sharpy specimens were made with a V-notch in the middle of the welded joint and with $\mathrm{V}$-notch $+4 \mathrm{~mm}$ and $-4 \mathrm{~mm}$ from the middle of the FSW welded joint (Figure 4).

\section{RESULTS}

Table 3 shows the macrostructures of cross-sections of the FSW joints with different welding parameters. Typical FSW zones: NZ, TMAZ and HAZ are observed on all the FSW joints. The temperature of the FSW does not exceed $80 \%$ of the melting temperature of the base metal. Depending on the welding parameters, different forms of grumble are observed. The grain size in the grumene zone is the smallest, while the grain is larger in the TMAZ and HAZ zones. The hottest grain is in the heat-affected zone (HAZ) near the thermo-mechanical zone (TMAZ). At this location, plastic deformations during welding are not pronounced, and thermal influence causes the formation of a smaller number of larger particles, which again causes a decrease in the hardness and the tensile strength.

Table 3: Macrostructure of cross-sections of FSW welded joints with different welding parameters

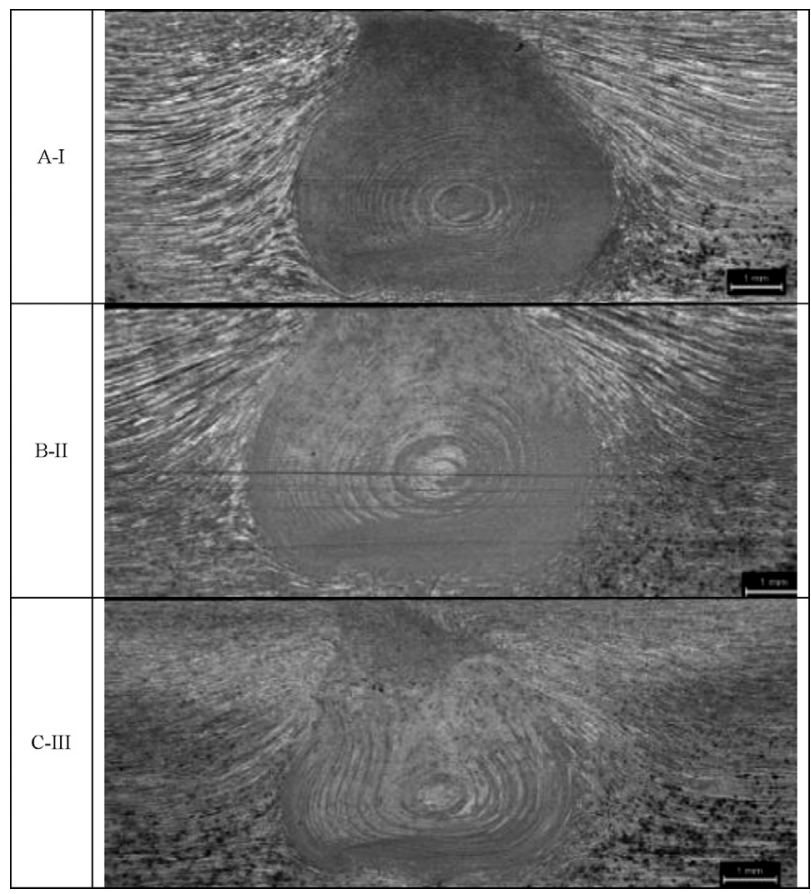

The tensile testing of FSW welded joints was performed for each of the welding parameters. The results of the tests are given in Table 4 .
Table 4: Tensile testing results

\begin{tabular}{|c|c|c|c|c|}
\hline $\begin{array}{c}\text { Sample } \\
\text { No. }\end{array}$ & $\begin{array}{c}\text { Yield } \\
\text { strength } \\
\text { (YS) MPa }\end{array}$ & $\begin{array}{c}\text { Ultimate ten- } \\
\text { sile strength } \\
\text { (UTS) MPa }\end{array}$ & $\begin{array}{c}\text { Elongation } \\
\%\end{array}$ & $\begin{array}{c}\text { Joint } \\
\text { efficiency } \\
\%\end{array}$ \\
\hline A-I & 303.7 & 398.33 & 2.3 & 0.83 \\
\hline B-II & 336.6 & 469.09 & 7.2 & 0.97 \\
\hline C-III & 339.7 & 373.34 & 0.65 & 0.77 \\
\hline
\end{tabular}

By comparing the yield strength (YS), ultimate tensile strength (UTS) and \% elongation of the FSW joints, the welded samples B-II with the welding parameters $750 / 116 \mathrm{rpm} /(\mathrm{mm} / \mathrm{min})$ have the highest values in relation to the welded samples A-I and C-III with the parameters $750 / 73$ and $750 / 150$. This indicates that $n / v=$ $750 / 116 \mathrm{rpm} /(\mathrm{mm} / \mathrm{min})$ are the optimal welding parameters of the AA2024 alloy with the selected tool.
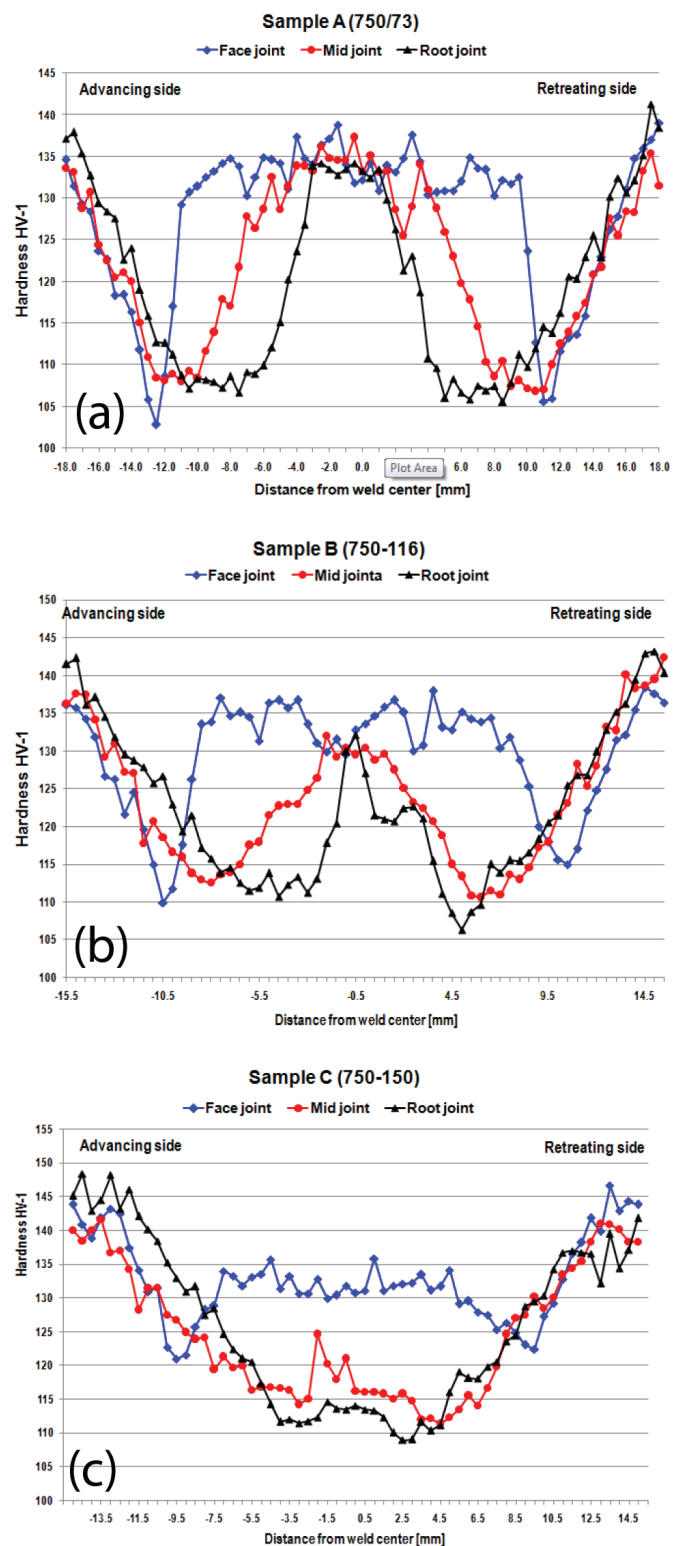

Figure 5: Hardness distribution across the welded joint 
The welded joint efficiency with these parameters is $97 \%$, which is extraordinary.

The results in Table 4 indicate that the greatest elongation occurred in the B-II welding parameter.

The testing of welded joints was also performed on bending, around the face, and around the root. The welded FSW joint has poor bending characteristics. Comparing the obtained bending test results, the largest bend angle to the first cracking phenomenon is for welding parameters $750 / 116$ and amounts to $42^{\circ}$.

Figure 5 shows the hardness distribution in the welded zones for all three welding parameters.

The hardness values in all the zones of the friction stir welded joint are less compared to the values of the hardness of the base metal. The heat generated during the FSW process causes softening of the welded joint due to the dissolution and the coarsening of the precipitates.

The distribution of the microhardness depends on the amount of heat generated under the shoulder of the tool and around the tool pin and plastic deformations. For the used friction stir welding parameters C-III, B-II and A-I, it can be concluded that the largest amount of heat is generated in the mixing zone for the welding parameters A-I.

By comparing the distribution of hardness, it can be seen that the FSW welded joint at a high welding speed $(150 \mathrm{~mm} / \mathrm{min})$ showed higher hardness values than at lower welding speeds (116 and $73 \mathrm{~mm} / \mathrm{min}$ ).

Comparing the hardness distribution for the welding parameter A-I (Figure 5a), B-II (Figure 5b) and C-III (Figure 5c), it is noted that the hardness of the sample

Table 5: Results of impact toughness and F-t and E-t diagrams for experimental samples in weld center

\begin{tabular}{|c|c|c|c|c|}
\hline & $K V / \mathrm{J} / \mathrm{cm}^{2}$ & $E / \mathrm{J}$ & $E_{i} / \mathrm{J}$ & $E_{p} / \mathrm{J}$ \\
\hline $\mathbf{O M}$ & 19.5 & 7.8 & 3 & 4.8 \\
\hline negx-3A-S & 12.62 & 5,05 & 1.64 & 3.41 \\
\hline $\mathbf{A}+4$ & 17.1 & 6.8 & 3 & 3.8 \\
\hline $\mathbf{A}-4$ & 13.6 & 5.5 & 2.1 & 3.4 \\
\hline $\mathbf{B}-\mathrm{S}$ & 12.62 & 6.7 & 1.7 & 5 \\
\hline $\mathbf{B}+4$ & 21.3 & 8.5 & 3.2 & 5.3 \\
\hline $\mathbf{B}-4$ & 11.1 & 4.5 & 1.4 & 3.1 \\
\hline $\mathbf{C}-\mathrm{S}$ & 14.2 & 5.7 & 2.4 & 3.3 \\
\hline $\mathbf{C}+4$ & 20.7 & 8.3 & 3.1 & 5.2 \\
\hline $\mathbf{C}-4$ & 12.8 & 5.1 & 1.9 & 3.2 \\
\hline
\end{tabular}

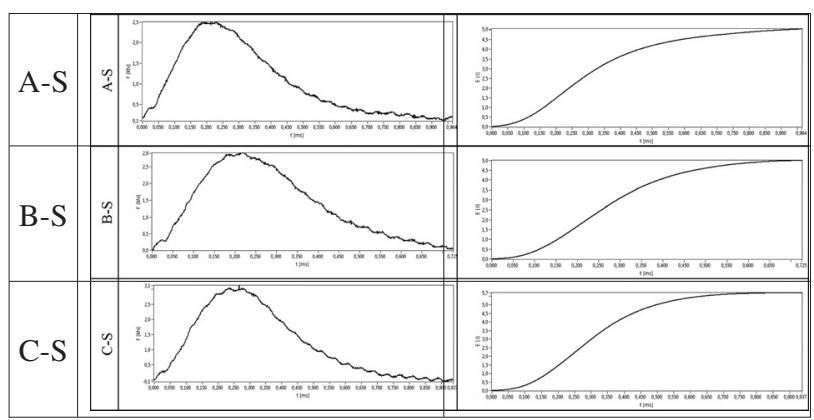

A-I in the stir region is uniform across the entire height. The FSW sample C-III shows the hardness difference in the height of the weld: the hardness of the root in the stir zone is between $110 \mathrm{HV}$ and $115 \mathrm{HV}$, while the hardness near the face of the weld is between $130 \mathrm{HV}$ and 135 HV.

The Charpy impact test results for the FSW joints are shown in Table 5.

The impact energy values were measured at three points of the notch: in the weld center, the notch on the advancing side in the $4 \mathrm{~mm}$ position from the weld center $(+4)$, and the notch on the side retreating at the 4 $\mathrm{mm}$ position from the weld center $(-4)$. For all the welded samples, the maximum impact-energy values are measured for the score on the advancing side.

The highest values of the impact energy were measured on samples welded with welding parameters $n=750 \mathrm{~min}^{-1}$ and welding speed of $116 \mathrm{~m} / \mathrm{min}$ for the notch on the side of the $\mathrm{B}+4$ progression side.

On all the welded samples, the smallest impact energy is on the samples with a notch on the retreating side.

Table 5 shows the F-t and E-t diagrams for specimens with a notch in the weld center for welded samples A-I, B-II and C-III.

\section{CONCLUSIONS}

This paper analyzes the effect of the process parameters on the mechanical properties of butt joints obtained by friction stir welding (FSW). On the basis of the examinations performed, given the results of the experiment and their comparison, the following conclusions can be drawn:

The largest frictional heat generated is for the welding parameters is A-I, and the minimum amount of heat for the welding parameters is C-III. The largest grain size was measured in the welding parameter A-I.

The profile of the distribution and allocation of the microhardness depends on the level of the temperature and the plastic deformation, which is the highest under the tool shoulder and around the pin.

A joint efficiency as high as $97 \%$ of the base metal could be achieved at B-II. The highest elongation of the welded joint is achieved with the welding parameters B-II and is $7.2 \%$.

The properties of FSW joints on bending are poor. The largest bend angle to the first cracking phenomenon is for welding parameters B-II and amounts to $42^{\circ}$.

The asymmetry of the welded joint and the changes in the metallurgical transformations occurring around the pin and under the shoulder of the tool during its combined moving, influence the value of the impact strength in various areas of the welded joint.

The relation between the number of revolutions of tools $n$ velocity of welding $v$ directly influences the value 


\section{MILČIĆ et al.: THE INFLUENCE OF PROCESS PARAMETERS ON THE MECHANICAL PROPERTIES..}

of the fracture toughness and energy that is required for the initiation and propagation of the crack;

The highest values of the impact energy were measured on samples welded with welding parameters $n=750 \mathrm{~min}^{-1}$ and welding speed of $116 \mathrm{~mm} / \mathrm{min}$ for the notch on the side of the $\mathrm{B}+4$ progression side.

\section{REFERENCES}

${ }^{1}$ W. M. Thomas, International Patent Application No. PCT/GB92/ 02203 and GB Application No. 9125978.8, 1991

${ }^{2}$ M. Miličić, P. Gladović, R. Bojanić, T. Savković, N. Stojić, Friction stir welding (FSW) process of copper alloys, Metalurgija, 55 (2016) $1,107-110$

${ }^{3}$ AWS D17.3/D17.3M An American National Standard: Specification for Friction Stir Welding of Aluminium Alloys for Aerospace Hardware, American Welding Society, Miami, Florida, 2010, 60

${ }^{4}$ R. S. Mishra, Z.Y. Ma, Friction stir welding and processing, Materials science and engineering, R 50 (2005), 1-78

${ }^{5}$ S. Zimmer, L. Langlois, J. Laye, R. Bigot, Experimental investigation of the influence of the FSW plunge processing parameters on the maximum generated force and torque, Int. J. Adv. Manuf. Technol., 47 (2010), 201-215

${ }^{6}$ A. K. Hussain, Evaluation of parameters of friction stir welding for aluminium AA6351 alloy, International journal of engineering science and technology, 2 (2010) 10, 5977-5984
${ }^{7}$ I. Radisavljević, A. Živković, V. Grabulov, N. Radović, Influence of pin geometry on mechanical and structural properties of butt friction stir welded 2024-T351 aluminum alloy, Hem. Ind., 69 (2015) 3, 323-330

${ }^{8}$ M. Perović, S. Baloš, D. Kozak, D. Bajić, T. Vuherer, Influence of kinematic factors of friction stir welding on the characteristics of welded joints of forged plates made of EN AW 7049 a aluminium alloy, Tehnical gazette, 24 (2017) 3, 723-728

${ }^{9}$ J. Q. Su, T. W. Nelson, R. Mishra, M. Mahoney, Microstructural investigation of friction stir welded 7050-T651 aluminium, Acta Mater., 51 (2003) 3, 713-729

${ }^{10}$ J. Ouyang, E. Yarrapareddy, R. Kovacevic, Microstructural evolution in the friction stir welded 6061 aluminum alloy (T6-temper condition) to copper, Journal of Materials Processing Technology, 172 (2006), 110-122

${ }^{11}$ R. Balokhonov, V. Romanova, E. Batukhtina, M. Sergeev, E. Emelianova, A numerical study of the microscale plastic strain localization in friction stir weld zones, Facta Universitatis Series: Mechanical Engineering, 16 (2018) 1, 77-86

${ }^{12}$ P. Podržaj, B. Jerman, D. Klobčar, Welding defects at friction stir welding, Metalurgija, 54 (2015) 2, 387-389

${ }^{13}$ M. Milcic, T. Vuherer, I. Radisavljevic, D. Milcic, Experimental investigation of mechanical properties on friction stir welded aluminum 2024 alloy, Springer Nature Switzerland AG 2019, 44-58 